\title{
TỔNG QUAN CHẨN ĐOÁN VÀ ĐIỀU TR! BỆNH HO GÀ
}

\section{Đỗ Thiện Hải
Nhi Trung ương}

\section{KHÁI NIỆM}

Ho gà là bệnh nhiễm trùng đường hô hấp cấp tính do vi khuẩn Bordetella pertussis gây ra, có khả năng lây nhiễm cao. Bệnh được mô tả lần đầu tiên từ những năm 1500. Đến năm 1670, Sydenham sử dụng thuật ngữ "pertussis", có nghĩa là ho dữ dội, thay cho từ "whooping cough"[1]. Đến nay, ho gà vẫn là nguyên nhân gây bệnh và tử vong cho trẻ em trên toàn thế giới, mặc dù tiêm chủng đã được phủ rộng [2]. Tại Bệnh viện Nhi Trung ương, mặc dù đã áp dụng nhiều biện pháp hiện đại trong điều trị nhưng tỷ lệ khỏi bệnh ra viện sau điều trị chiếm 79,6\% (86/108); Tỷ lệ tử vong $2,8 \%(3 / 108)$, trong đó $7,5 \%(3 / 40)$ trẻ dưới 2 tháng tuổi [3].

\section{DICH TẼ̃ HOC}

\subsection{Tình hình mắc bệnh}

Bệnh xảy ra thành dịch lẻ tẻ ở tất cả các nước, chu kỳ dịch xuất hiện khoảng 2-5 năm, bệnh biểu hiện chủ yếu ở trẻ dưới 5 tuổi, các ca bệnh nặng và tử vong hay gặp ở trẻ độ tuổi bú mẹ. Theo ước tính của Tổ chức $Y$ tế thế giới, bệnh ho gà là nguyên nhân gây tử vong ở 63.000 trẻ dưới 5 tuổi, đặc biệt ở các nước đang phát triển[4],[5],[6].

Vắc xin phòng ho gà đã được đưa vào Chương trình tiêm chủng mở rộng (EPI) của WHO vào năm 1974. Theo ước tính của WHO thì trong năm 2008 có khoảng 16 triệu trường hợp mắc bệnh, $95 \%$ trong số này ở các nước đang phát triển và khoảng 195.000 trường hợp tử vong mặc dù ước tính tỷ lệ trẻ sơ sinh được chủng ngừa ba liều vắc xin cơ bản trên toàn thế giới là khoảng $82 \%$. Trong cùng năm, tiêm chủng đã giúp tránh được khoảng 680.000 ca tử vong. Báo cáo gần đây cho thấy, hàng năm vẫn có hàng trăm nghìn ca mắc bệnh, năm 2018 có 151.074 ca bệnh được báo cáo [7].

Tại Mỹ, trong giai đoạn trước tiêm chủng, ho gà là nguyên nhân hàng đầu gây tử vong do các bệnh truyền nhiễm ở trẻ em dưới 14 tuổi. Việc sử dụng rộng rãi vắc xin phòng ho gà từ cuối năm 1940 đã làm giảm tỷ lệ mắc bệnh hơn 100 lần vào những năm 1970. Tuy nhiên, giai đoạn 1990 đến nay, cho thấy xu hướng gia tăng trở lại bệnh ho gà với một số đỉnh dịch vào các năm 2004 -2005, 2009, 2012. Trong đó quan sát thấy, tỷ lệ mắc bệnh cao nhất ở trẻ nhỏ dưới 1 tuổi, đặc biệt trẻ dưới 3 tháng, số ca bệnh tử vong chủ yếu là trẻ em dưới 2 tháng tuổi chưa được tiêm phòng[8].

Nghiên cứu giám sát huyết thanh học đa quốc gia ở trẻ thanh thiếu niên châu Á cho thấy có khoảng 4,8\% trẻ có bằng chứng huyết thanh học nhiễm ho gà kể cả trẻ đã được tiêm chủng 3 mũi vắc xin cơ bản [9]. Tại khu vực ASEAN, theo Yeung và cộng sự năm 2017, ước tính rằng trong số 179,5 triệu người dưới 5 tuổi sống ở Đông Nam Á vào năm 2014 , có khoảng 6,3 triệu trẻ $(3,5 \%)$ mắc bệnh ho gà dẫn đến khoảng 42.500 ca tử vong [10].

Tại Việt Nam, trước khi triển khai Chương trình TCMR Quốc gia, ho gà là bệnh phổ biến với khoảng 50.000-100.000 ca mắc và hàng chục ca tử vong được báo cáo mỗi năm, chủ yếu ở trẻ nhỏ. Việc tiêm chủng vắc xin ho gà ở trẻ em dưới 
1 tuổi ở Việt Nam được duy trì đạt tỷ lệ trên $90 \%$ liên tục trong nhiều năm, nhờ vậy tỷ lệ mắc ho gà ở trẻ em giảm từ 84,4/100.000 dân năm 1984 xuống chỉ còn $0,46 / 100.000$ dân vào năm 2004 . Chương trình tiêm chủng mở rộng đã phòng được bệnh ho gà cho hàng triệu trẻ em và cứu

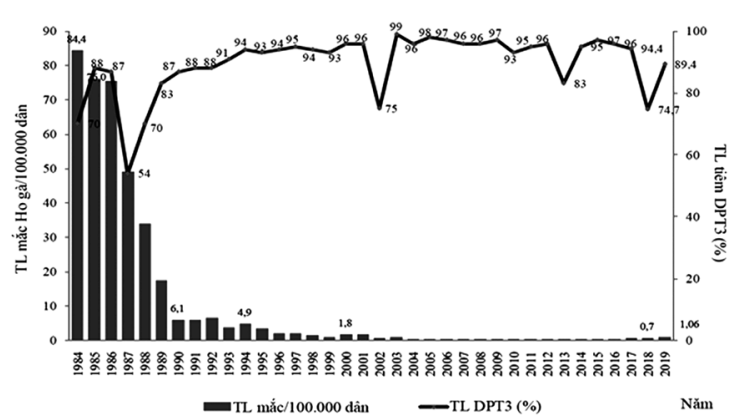

Hình 1. Tỷ lệ tiêm chủng vắc xin phòng bệnh ho gà và tỷ lệ mắc ho gà/100.000 dân, 1984-2019 (Nguồn: TCMR-2020)

\subsection{Vùng địa lý, thời điểm mắc bệnh}

Tại Việt Nam, bệnh phân bố hầu khắp các vùng miền và các tỉnh, tuy nhiên, bệnh có tỷ lệ mắc cao tại các tỉnh thành phố mật độ dân số đông. Bệnh xảy ra rải rác trong năm, hay gặp hơn vào mùa đông xuân [12],[13].

\subsection{Tác nhân gây bệnh}

Giống Bordetella thuộc họ Alcaligenaceae, gồm 10 loài khác nhau. Trong đó, Bordetella pertussis là nguyên nhân chính gây bệnh ho gà. Các loài khác như B.parapertussis, B.bronchiseptica và B.holmessi cũng có thể gây bệnh giống ho gà [5].

Bordetella pertussis có nhiều kháng nguyên tham gia cơ chế bệnh sinh gây bệnh ho gà: độc tố ho gà - Pertussis toxin (PT), Filamentous hemagglutinin (FHA- kháng nguyên bề mặt gây bám dính biểu mô đường hô hấp), Pertactin (PRN), Agglutinogen (FIM), độc tố Adenylate cyclase ( $\mathrm{AC})$, độc tố tế bào khí quản - Tracheal cytotoxin (TCT)...[14],[15].

\subsection{Nguồn lây}

Nguồn lây có thể từ các trường hợp đang mắc bệnh hoặc người lành mang vi khuẩn. ở trẻ lớn được sinh mạng của hàng ngàn trẻ. Đặc biệt kể từ khi triển khai tiêm nhắc mũi 4 vắc xin ho gà thì số mắc hàng năm giai đoạn (1998-2012) ở mức thấp $0,1-0,32 / 100.000$ dân. Tuy nhiên, tỷ lệ này trong 5 năm gần đây 2015 - 2020 có xu hướng tăng nhẹ lên 0,7-1,06/100.000 dân[11].

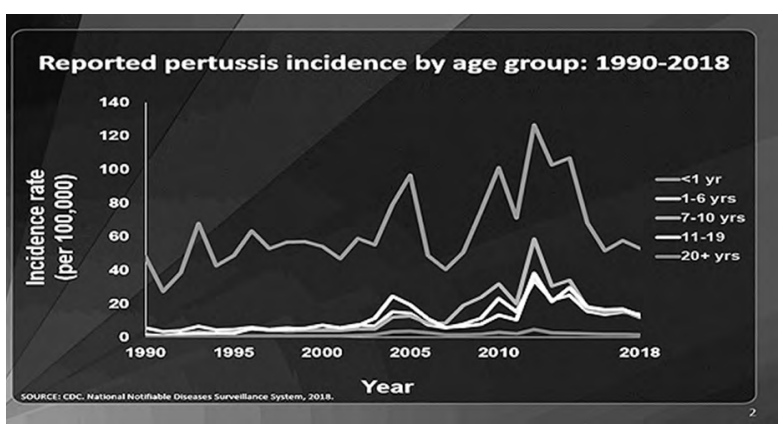

Hình 2. Tỷ lệ mắc ho gà / 100.000 dân theo nhóm tuổi tại Mỹ, giai đoạn 1990-2018

và người lớn mang vi khuẩn thường chỉ gây bệnh ho gà không điển hình, khi tiếp xúc với trẻ nhỏ có thể tạo nguồn lây thông qua giọt bắn khi ho, hắt hơi... đặc biệt là những người sinh sống trong cùng gia đình với trẻ nhỏ chưa được tiêm vắc xin phòng bệnh. Tại Bệnh viện Nhi Trung ương, báo cáo của Đỗ Thiện Hải và cộng sự (2019) cho thấy tỷ lệ người chăm sóc trẻ mang vi khuẩn gây bệnh khá cao, mẹ $(52,9 \%)$, cha $(19,6 \%)$, người thân trong gia đình (23,5\%), người chăm sóc khác $(9,8 \%)$ [16].

Tại Mỹ, báo cáo trong 7 năm (2006 - 2013) tại 7 bang cho thấy tỷ lệ trẻ dưới 2 tháng chiếm $24,2 \%$ và khoảng $66 \%$ trường hợp có nguồn lây là trong gia đình, thường gặp là anh chị em ruột $(35,5 \%)$, mẹ $(20,6 \%)$, cha $(10,0 \%)$; và độ tuổi trung bình của nguồn lây bệnh là 14 tuổi (0-74); tuổi trung bình của anh chị em là 8 tuổi [17].

\subsection{Khối cảm nhiễm và đáp ứng miễn dịch}

2.5.1. Khối cảm nhiễm: Tất cả mọi người, giới tính đều có thể mắc bệnh. Người lớn có thể tái nhiễm sau thời gian dài mắc bệnh do suy giảm kháng thể bảo vệ [18].

ở trẻ em, lứa tuổi thường mắc bệnh là dưới 3 tháng do chưa đến thời điểm tiêm chủng và 
kháng thể từ mẹ truyền sang còn hạn chế, tỷ lệ này trong nghiên cứu tại Bệnh viện Nhi Trung ương là vào khoảng $78,7 \%$ và $89,8 \%$ chưa tiêm phòng [12]. Bệnh gặp ở cả trẻ trai và gái, tuy nhiên trẻ trẻ gái có tỷ lệ cao hơn chiếm 53,5\% (68/127).

Trong những năm gần đây nhóm trẻ dưới 2 tháng là đối tượng có nguy cơ mắc ho gà cao nhất (với tỷ lệ khoảng 200/100.000 vào năm 2004). Trẻ nhũ nhi dưới 6 tháng là nhóm nguy cơ cao nhất mắc ho gà phải nhập viện và có biến chứng; từ 1980 đến 2004, 235 ca tử vong liên quan đến ho gà ở trẻ dưới 6 tháng được báo cáo cho CDC [19]. Ngoài ra, cuối những năm 1990, các nghiên cứu ở Đức (nơi xuất hiện dịch ho gà do tiêm phòng ho gà không được tiến hành thường xuyên) đã xuất hiện nhiều trường hợp ho gà ở người lớn, nhiều người trong số đó đã từng mắc bệnh ho gà khi còn nhỏ [18].

2.5.2. Đáp ứng miễn dịch: ở người sau khi nhiễm $B$. pertussis tự nhiên sẽ sản sinh ra lgG và $\lg \mathrm{A}$. IgA được phát hiện ở chất nhày trước khi phát hiện IgG trong huyết thanh. IgA và IgG đặc hiệu chống ho gà có thể được cung cấp cho trẻ mới sinh qua sữa non hoặc từ mẹ truyền sang con và người ta đã chứng minh rằng chúng có thể bảo vệ trẻ khi mới sinh [5]. Việc tiêm phòng vắc xin cho trẻ em tạođáp ứng miễn dịch sinh kháng thể $\lg M$ và lgG là chủ yếu[19].Thời gian tồn tại kháng thể ở mức có khả năng bảo vệ cho trẻ sau khi tiêm vắc xin sẽ giảm dần theo thời gian. Sau 3 - 5 năm thì tỷ lệ này giảm còn khoảng $41 \%$ và sau khi tiêm nhắc lại thì tăng lên trên $90 \%[20]$. Các nghiên cứu mở rộng gần đây đã cho thấy rằng thời gian bảo vệ chống lại ho gà của cả nhiễm bệnh tự nhiên hoặc được tiêm vắc xin tương đối ngắn. Các ca ho gà điển hình cũng xuất hiện ở người lớn và rõ ràng đó là những trường hợp tái nhiễm, điều đó chứng tỏ miễn dịch chống ho gà cũng không tồn tại suốt đời mà giảm dần theo thì gian [21],[22].

Do vậy, việctiêm vắc xin nhắc lại định kỳ cho trẻ và bố mẹ của trẻ [23], sẽ làm tăng khả năng bảo vệ trẻ thông qua ngăn ngừa sự lây truyền ho gà và tạo kháng thể có thể truyền cho con trong những tháng đầu đời[24].

\subsection{Sinh bệnh học}

Vi khuẩn ho gà xâm nhập vào biểu mô đường hô hấp tiết ra độc tố ho gà PT và các yếu tố độc lực khác gây tổn thương lớp biểu mô và kích thích niêm mạctăng tiết nhầy,đồng thời các tổ chức bị tổn thương tăng giải phóng histamin tác động lên niêm mạc đường hô hấp gây ra những cơn ho không kiềm chế được [5].

Độc tố ho gà một mặt kích thích trực tiếp vào các thụ cảm thần kinh của niêm mạc đường hô hấp gây ra cơn ho điển hình. Mặt khác, độc tố còn tác động trực tiếp đến trung khu hô hấp ở hành tủy, gây ra những ổ hưng phấn, gây ra những biểu hiện rối loạn hô hấp, như cơn ho phản xạ kéo dài, có thể ngừng thở[15]. Sự lan truyền của độc tố ở hệ thần kinh trung ương có thể dẫn tới tình trạng viêm não. Ngoài ra, hiện tượng tăng lympho bào điển hình ở máu ngoại vi do độc tố của vi khuẩn gây kích thích hệ miễn dịch tế bào và còn làm tăng sản xuất insulin tại các đảo tụy gây ra hạ đường huyết[5].

Giả thiết cho rằng ở trẻ sơ sinh và trẻ dưới 6 tháng có tiểu động mạch phổi, hệ đông máu và tiêu fibrin chưa trưởng thành, tăng bạch câu lympho góp phần trực tiếp gây ra hội chứng tăng cô đặc máu, tăng đông và gây tắc tiểu động mạch phổi, cản trở lưu lượng máu phổi gây tăng áp lực động mạch phổi. Sinh thiết phổi sau tử vong của các bệnh nhân ho gà nặng này thấy tình trạng hoại tử mô lan tỏa và các cục máu đông trong tiểu động mạch phổi có chứa rất nhiều bạch cầu[15].

\section{CHẨN ĐOÁN}

\subsection{Triệu chứng lâm sàng}

Bệnh ho gà ở trẻ nhỏ có triệu chứng khá điển hình, nhưng ở trẻ lớn và người lớn thì thường không có cơn ho điển hình và cũng ít gây biến chứng nặng. Báo cáo tại Bệnh viện Nhi Trung ương cho thấy các triệu chứng thường gặp như ho cơn dài $(92,9 \%)$, đỏ mặt $(98,4 \%)$, tím tái $(81,1 \%)$, tăng tiết đờm dãi $(94,5 \%)[16]$.

\subsubsection{Thể điển hình}

Thường gặp ở trẻ nhỏ chưa được tiêm phòng, 
thời gian ủ bệnh từ 3 đến 12 ngày tiếp theo là sự xuất hiện các triệu chứng của thời kỳ khởi phát.

a. Thời kỳ khởi phát (giai đoạn viêm long): Thường từ 3-14 ngày, ở trẻ nhỏ dưới 3 tháng giai đoạn này thường chỉ kéo dài một vài ngày hoặc không có, với các biểu hiệnkhông điển hình như ngạt mũi, chảy nước mũi, hắt hơi, đau rát họng, dần dần chuyển thành ho cơn.

\section{b. Thời kỳ toàn phát (giai đoạn ho cơn)}

Kéo dài 1-2 tuần, trẻ nhỏ dưới 3 tháng giai đoạn này kéo dài hơn, xuất hiện những cơn ho gà điển hình, xảy ra bất chợt, vô cớ hay khi có kích thích, cả ngày và đêm, ho cả khi trẻ đang chơi, đang ăn hoặc khi quấy khóc. Cơn ho diễn biến qua 3 giai đoạn: ho, thở rít và khạc đờm.

- Ho: ho rũ rượi thành cơn, mỗi cơn từ 15-20 tiếng ho liên tiếp. Khi ho lưỡi bị đẩy ra ngoài, lâu dần dẫn đến loét hãm lưỡi (ở trẻ chưa có răng không có triệu chứng này). Ho nhiều làm trẻ thở yếu dần có lúc như ngừng thở, mặt tím tái, mắt đỏ, tĩnh mạch cổ nổi, chảy nước mắt nước mũi.

- Thở rít vào: xuất hiện cuối cơn ho do khí hít vào đi qua thanh môn vẫn đóng một phần.

- Khạc đờm: các cơn ho có thể kết thúc với sự bài xuất ra nút nhầy đặc quánh dính là chất bài tiết của khí quản cô đặc, vi nhung mao rụng, và biểu mô đường hô hấp bị hoại tử, trực khuẩn ho gà và bạch cầu lympho.

- Sau mỗi cơn ho, trẻ bơ phờ mệt mỏi, có thể nôn, vã mồ hôi, mạch nhanh, thở nhanh. Kèm theo có thể thấy một số triệu chứng sau: sốt nhẹ hoặc không sốt, mặt và mi mắt nặng, loét hãm lưỡi, nghe phổi trong cơn ho có thể thấy một số ran phế quản.

- Các cơn ho tăng dần về số cơn và mức độ nặng của cơn trong vòng vài ngày đến một tuần và duy trì trạng thái nặng trong vài ngày đến vài tuần, đôi khi có cơn ho kéo dài vài giờ.

\section{c. Thời kỳ lui bệnh và hồi phục}

- Kéo dài khoảng 2-4 tuần. Số cơn ho giảm dần, thời gian mỗi cơn ngắn lại, cường độ ho giảm, khạc đờm ít, sau đó hết hẳn. Tinh trạng toàn thân tốt dần lên, trẻ ăn được và vui chơi bình thường.

- Tuy nhiên, một số trẻ xuất hiện những cơn ho phản xạ kéo dài, thậm chí tới 1-2 tháng. ở trẻ nhỏ dưới 3 tháng,thời gian ho có thể kéo dài suốt năm đầu.

3.1.2. Thể thô sơ: Biểu hiện viêm đường hô hấp trên như sốt nhẹ, ho, hắt hơi, chảy mũi... thể này thường gặp ở trẻ lớn, đã tiêm phòng nhưng không tiêm nhắc lại.

\subsubsection{Thểnhe}

- Cơn ho nhẹ, ngắn, và không điển hình, không khạc đờm nhiều.

- Thường gặp ở trẻ em đã tiêm vắc xin phòng ho gà nhưng kháng thể thấp và tồn lưu ngắn. Thể này thường khó chẩn đoán.

Bảng 1. Đánh giá mức độ nặng của cơn ho gà

(Nguồn: Principles and Practice of Pediatric infectious diseases - 2008)[4]

\begin{tabular}{|l|l|l|}
\hline \multicolumn{1}{|c|}{ Các tham số } & \multicolumn{1}{|c|}{ Dấu hiệu tiên lượng tốt } \\
\hline Thời gian cơn ho & $<45$ giây & Dấu hiệu nặng \\
\hline Thái độ xử trí cơn ho & Lo lắng, lúng túng & Không biết làm gì \\
\hline Đặc điểm cơn ho & $\begin{array}{l}\text { Tiếng ho to, mạnh, liên tực, không ngớt cho đến khi có } \\
\text { luồng không khí được đẩy ra. }\end{array}$ & Nôn/nghẹt thở/thở hổn hển sau ho \\
\hline Màu sắc da & Đỏ & Xanh tái \\
\hline Nhịp tim nhanh & Kiểm soát được < 30 giây sau ngừng ho & Kéo dài \\
\hline $\begin{array}{l}\text { Nhịp tim chậm } \\
\text { (<60 ở trẻ nhỏ < 3 tháng) }\end{array}$ & Giải quyết được sau khi ngừng ho mà không cần kích thích. & Kéo dài và đòi hỏi phải có kích thích \\
\hline Nhu cầu oxy & $<30$ giây sau khi ngừng ho & Kéo dài \\
\hline Nút đờm nhầy & Tự khạc ra, tự long đờm & Tắc nghẽn cần phải hút \\
\hline Nhịp tự thở & Ngay lập tức và nhịp thở sâu & Ngừng thở, nhịp thở yếu \\
\hline Tiếng thở rít & Mạnh & Không có \\
\hline Tình trạng sau cơn ho & Mệt & Không đáp ứng \\
\hline
\end{tabular}




\subsection{Cận lâm sàng}

\subsubsection{Xét nghiệm thường quy}

- Tổng phân tích tế bào máu: Bạch cầu tăng (15.000 - 100.000/mcL), tăng số lượng bạch cầu lympho thường trong giai đoạn viêm long.

- Chụp Xquang ngực: Có thể thấy hình ảnh đậm rốn phổi, phù phổi hoặc xẹp phế nang. Hình ảnh đông đặc nhu mô phổi gợi ý nhiễm khuẩn thứ phát. Có thể gặp tràn khí màng phổi, tràn khí trung thất và tràn khí dưới da.

\subsubsection{Xét nghiệm xác địnhh căn nguyên (nếu có} điều kiện)

Kỹ thuật phòng xét nghiệm để xác định nhiễm B.pertussis bằng nuôi cấy đã tồn tại hơn 90 năm, phương pháp phát hiện kháng thể trong huyết thanh được ghi nhận vào năm 1916.

Phương pháp chẩn đoán phòng xét nghiệm phổ biến hiện nay bao gồm nuôi cấy, $P C R$, và ELISA. Mẫu bệnh phẩm có thể được lấy từ họng, đờm, mũi trước. Việc sử dụng công nghệ Polymerase Chain Reaction (PCR) giúp cho việc chẩn đoán nhanh chóng và có độ nhạy cao hơn so với nuôi cấy bốn lần và có thể đạt $61 \%$ và độ đặc hiệu đạt $88 \%[25]$.

Xét nghiệm kháng thể huỳnh quang trực tiếp (DFA) sử dụng kháng thể đặc hiệu với B.pertussis và B.parapertussis tìm kháng nguyên trong dịch tiết mũi họng là một test nhanh nhưng ít sử dụng vì độ tin cậy hạn chế [8].

Các xét nghiệm kháng thể lgA và lgM kháng độc tố ho gà PT hoặc những kháng thể khác đều không đáng tin cậy trong chẩn đoán ho gà ở giai đoạn sớm. Xét nghiệm huyết thanh tìm kháng thể B.pertussis ít nhất 2 tuần sau khi có triệu chứng ho. Xét nghiệmđịnh lượng kháng thể Immunoglobulin $\mathrm{G}(\mathrm{IgG})$ với độc tố ho gà (Pertussis toxin - PT) tăng > 2 SD trên mức giá trị trung bình của quần thể đã có miễn dịch $(\approx 100$ $\mathrm{EU} / \mathrm{mL}$ ) hoặc nồng độ kháng thể lgG tăng 2-4 lần sau 2-3 tuần có ý nghĩa gợi ý chẩn đoán nhiễm bệnh [7].

\subsection{Chẩn đoán xác định}

Theo Hội nghị ho gà toàn cầu (GPI) năm 2011 đã dựa trên nhiều nghiên cứu lâm sàng và thống nhất đưa ra tiêu chuẩn chẩn đoán lâm sàng ca bệnh ho gà (áp dụng khi không có điều kiện xét nghiệm).

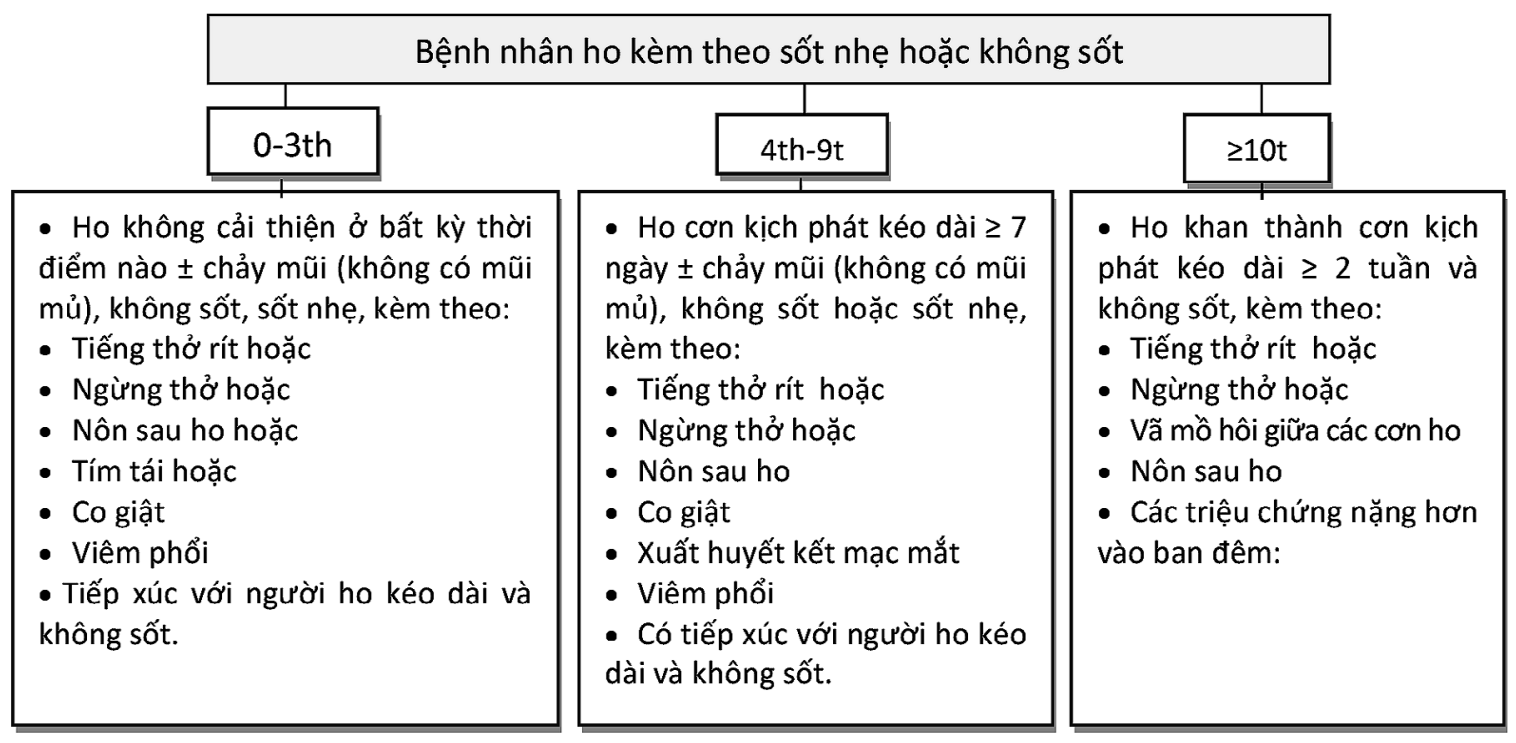

Sơ đồ 1. Tiêu chuẩn chẩn đoán lâm sàng bệnh ho gà

(Nguồn: Khuyến cáo của Hội nghị ho gà toàn câu - 2011; Clinical Definitions of Pertussis: Summary of GPI roundtable meeting, Feb. 2011) 
- Khi bệnh nhân có ít nhất 1 tiêu chuẩn chẩn đoán ho gà thì nên điều trị.

- Chẩn đoán xác định: Đủ tiêu chuẩn chẩn đoán ca bệnh lâm sàng và xét nghiệm vi sinh (nuôi cấy, PCR hoặc xét nghiệm huyết thanh), hoặc có tiếp xúc trực tiếp với người được xác định mắc ho gà.

\subsection{Chẩn đoán biến chứng}

Tỷ lệ các biến chứng phụ thuộc vào tuổi, tình trạng miễn dịch, và đáp ứng của hệ thống y tế. Trẻ nhỏ dưới 6 tháng tuổi có tỷ lệ mắc biến chứng và tử vong cao, đặc biệt trẻ dưới 2 tháng tuổi [12], [15].

- Nhiễm trùng bội nhiễm: viêm phổi, viêm tai giữa. Trong báo cáo tại Bệnh viện Nhi Trung ương thì tỷ lệ trẻ có biến chứng viêm phổi là 53 - 82,7\% [16],[13].

- Suy hô hấp: do ngừng thở, viêm phổi, hoặc tăng áp phổi, do sự tắc nghẽn trong cơn hay tình trạng thiếu oxy sau cơn ho. Đôi khi, ngừng thở hoặc nhịp chậm xảy ra mà không có ho.

- Tăng áp lực động mạch phổi (ALĐMP) (chuyển đơn vị hồi sức cấp cứu): Xác định sớm tăng áp lực động mạch phổi khi có tình trạng co thắt, thở rít... Báo cáo tại Bệnh viện Nhi khi khảo sát bệnh nhi mắc bệnh nặng nằm tại khoa Hối sức thì tỷ lệ có tăng áp động mạch phổi là 62\% [13].

- Tổn thương thần kinh trung ương: Co giật, xuất huyết liên quan đến do thiếu oxy do cơn ho dài và ngừng thở ở trẻ nhỏ.

- Tăng áp lực trong lồng ngực và ổ bụng trong cơn ho có thể gây ra các biến chứng như xuất huyết kết mạc và củng mạc mắt, chấm xuất huyết ở nửa trên cơ thể, chảy máu cam, tràn khí màng phổi và tràn khí dưới da, thoát vị bẹn và rốn, tiểu tiện không tự chủ, rách hãm lưỡi.

- Hạ natri máu do sự bài tiết không hợp lý hormone chống bài niệu kết hợp với viêm phổi gây ra.

\subsection{Chẩn đoán phân biệt}

- Trẻ nhỏ: cần phân biệt với hạ đường huyết, xuất huyết não do có các triệu chứng ngừng thở, co giật, không sốt; Nếu có triệu chứng viêm đường hô hấp dưới phân biệt với nhiễm C. Trachomatis, nhiễm virus hợp bào đường hô hấp (respiratory syncytial virus - RSV).

- Trẻ lớn: phân biệt với các căn nguyên gây viêm đường hô hấp khác như nhiễm Adenovirus, Mycoplasma.

\subsection{Yếu tố tiên lượng nặng}

Tăng bạch cầu máu là đặc điểm nổi bật ở trẻ có tình trạng bệnh nặng, bạch cầu máu tăng trên 100.000 tế bào/mcL liên quan đến tử vong trong bệnh ho gà[26].

Tăng áp lực động mạch phổi và viêm phổi là những biến chứng nặng nhất của bệnh ho gà.

Bệnh nhi có các biến chứng nặng phải can thiệp tại đơn vị hồi sức như thở oxy, thở máy, suy tuần hoàn... thì có tỷ lệ tử vong lên đến 33,3\% [13].

\section{4. ĐIỀU TR!}

\subsection{Nguyên tắc điều trị}

- Điều trị sớm khi có triệu chứng nghi ngờ mắc ho gà với mục tiêu là hạn chế biến chứng, hạn chế cơn ho, giảm mức độ nặng của bệnh.

- Tiêu chuẩn nhập viện:

+ Tất cả trẻ nhỏ dưới 3 tháng đều phải nhập viện.

+ Trẻ trên 3 tháng nhập viện khi có cơn ho nặng.

\section{2. Điều trị cụ thể}

\subsubsection{Chăm sóc}

- Cho trẻ nghỉ ngơi trong phòng yên tĩnh, ít ánh sáng, thoải mái, tránh các yếu tố nguy cơ như khói thuốc lá, bụi, khô, tiếng ồn, ...

- Tăng cường dinh dướng bằng các phương án phù hợp nhưa ăn nhiều bữa với số lượng ít hơn hàng ngày, ăn qua sonde hoặc nuôi dưỡng tĩnh mạch.

- Theo dõi chặt chẽ, đánh giá mức độ nặng của bệnh, phát hiện sớm cơn ngừng thở, co giật, các biến chứng khác thường xảy ra trong thời kỳ toàn phát. 


\subsection{2. Điều trị kháng sinh}

Kháng sinh cần chỉ định sớm ngay khi nghi ngờ hoặc chẩn đoán xác định mắc ho gà. Vi khuẩn B.parapertussis vẫn nhạy cảm với erythromycin, các macrolide thế hệ mới, quinolone, các cephalosporin thếhệ ba và meropenem. Các thuốc khác như ampicillin, rifampin, và trimethoprimsulfamethoxazole có hiệu quả thấp, còn các cephalosporins thế hệ một và thế hệ hai thì không có hiệu quả... Gần đây đã thấy có tình trạng vi khuẩn kháng macrolid trên lâm sàng với bằng chứng là vẫn tìm thấy vi khuẩn trong dịch họng mắc dù đã được dùng kháng sinh nhóm macrolid.

Bảng 2. Khuyến cáo sử dụng kháng sinh cho điều trị và dự phòng sau phơi nhiễm ho gà (Nguồn: Principles and Practice of Pediatric Infectious Diseases 2008)

\begin{tabular}{|c|c|c|c|c|}
\hline \multirow{2}{*}{ Các thuốc } & \multicolumn{4}{|c|}{ Nhóm tuổi } \\
\hline & $<1$ tháng & 1-5 tháng & > 6 tháng, trẻ lớn & Người lớn \\
\hline $\begin{array}{l}\text { Thuốc ưu tiên } \\
\text { Azithromycin }\end{array}$ & $\begin{array}{l}10 \mathrm{mg} / \mathrm{kg} / \mathrm{ngày}, \\
\text { ngày } 1 \text { lần x } 5 \text { ngày }\end{array}$ & $\begin{array}{l}10 \text { mg/kg/ngày, } \\
\text { ngày } 1 \text { lần x } 5 \text { ngày }\end{array}$ & $\begin{array}{l}10 \mathrm{mg} / \mathrm{kg} \text { (tối đa } 500 \mathrm{mg} \text { )/ } \\
\text { ngày đâu; sau đó } 5 \mathrm{mg} / \mathrm{kg} \\
\text { (tối đa } 250 \mathrm{mg} \text { )/ngày trong } \\
\text { các ngày } 2-5\end{array}$ & $\begin{array}{l}500 \text { mg một ngày đầu; sau } \\
\text { đó } 250 \text { mg mỗi ngày trong } \\
\text { các ngày 2-5 }\end{array}$ \\
\hline Clarithromycin & Không khuyến cáo & $\begin{array}{l}15 \text { mg/kg/ngày, chia } 2 \\
\text { lần x } 7 \text { ngày }\end{array}$ & $\begin{array}{l}15 \mathrm{mg} / \mathrm{kg} / \mathrm{ngày} \text { (tối đa } 1 \mathrm{~g} / \\
\text { ngày), chia } 2 \text { lần x } 7 \text { ngày }\end{array}$ & 1 g/ngày chia 2 lần $x 7$ ngày \\
\hline Erythromycin & Không dùng & $\begin{array}{l}40-50 \text { mg/kg/ngày chia } \\
4 \text { lần x } 14 \text { ngày }\end{array}$ & \begin{tabular}{|l|}
$40-50 \mathrm{mg} / \mathrm{kg} / \mathrm{ngày}$ (tối đa 2 \\
$\mathrm{~g} / \mathrm{ngày}$ ) chia 4 lần x 14 ngày
\end{tabular} & 2 g/ngày chia 4 lần x 14 ngày \\
\hline $\begin{array}{l}\text { Thuốc thay thế } \\
\text { TMP-SMX }\end{array}$ & Chống chỉ định & $\begin{array}{l}\text { - Trẻ < } 2 \text { tháng: Chống } \\
\text { chỉ định } \\
\text { Trẻ > } 2 \text { tháng: } \\
\text { TMP } 8 \mathrm{mg} / \mathrm{kg} / \mathrm{ngày} \\
\text { SMX: } 40 \mathrm{mg} / \mathrm{kg} / \mathrm{ngày} \\
\text { chia } 2 \text { lần × } 14 \text { ngày }\end{array}$ & $\begin{array}{l}\text { TMP } 8 \text { mg/kg/ngày-SMX } \\
40 \text { mg/kg/ngày (tối đa TMP } \\
320 \text { mg/ngày) chia } 2 \text { lần } \times \\
14 \text { ngày }\end{array}$ & $\begin{array}{l}\text { TMP } 320 \text { mg-SMX } 1600 \text { mg/ } \\
\text { ngày chia } 2 \text { lần } \times 14 \text { ngày }\end{array}$ \\
\hline
\end{tabular}

Ghi chú: TMP-SMX: trimethoprim-sulfammethoxazole.

\subsubsection{Một số điều trị khác}

- Corticosteroid: không được khuyến cáo

- Các chất kích thích $\beta 2$ - adrenergic như albuterol: Tác dụng còn tranh cãi.

- Một số nghiên cứu cho thấy, sử dụng huyết thanh có nồng độ kháng thể cao (từ người trưởng thành đã tiêm vắc xin ho gà vô bào) tiêm bắp giúp làm giảm đáng kể cơn ho rít ở trẻ nhũ nhi được điều trị ngay trong tuần đầu của bệnh.

- Kháng thể đặc hiệu của ho gà (Pertussis immune globulin intravenous P-IGIV): hiệu quả chưa rõ ràng.

4.2.4. Điều trị suy hô hấp (Chuyển đến đơn vị chăm sóc tích cực)

Tỷ lệ trẻ mắc bệnh phải can thiệp hỗ trợ hô hấp các mức độ khác nhau chiếm tỷ lệ khá cao $(25,2$ - 93\%) [16],[13].

- Hạn chế tối đa các kích thích có thể làm khởi phát cơn ho gà như khói thuốc lá, bụi, các kích thích hóa học. Các thuốc như corticosteroids, salbutamol, kháng histamine và thuốc ức chế receptor leukotriene (monteleukast) không có vai trò giảm cơn ho kịch phát trong ho gà.

- Đặt tư thế trẻ nằm đầu cao, thoải mái, làm thông thoáng đường thở, tránh tắc nghẽn đường thở do xuất tiết.

- Cho bệnh nhân thở oxy khi có các biểu hiện suy hô hấp: thở nhanh, gắng sức, tím tái, $\mathrm{SpO}_{2}<92 \%$ khi thở khí trời. Đặt ống nội khí quản và hỗ trợ hô hấp sớm khi có các dấu hiệu suy hô hấp nặng và/hoặc có dấu hiệu suy tuần hoàn. 


\subsubsection{An thần, giãn cơ}

- Chỉ định an thần: khi cơn ho kịch phát, kích thích gây tình trạng chống máy, tăng tiết catecholamine gây tăng sức cản mạch phổi làm tồi tệ thêm tình trạng tăng áp phổi. Các thuốc có thể sử dụng gồm phenobacbital (uống), midazolam, fentanyl.

- Chỉ định giãn cơ: nếu trẻ còn kích thích, chống máy khi đã sử dụng an thần tối ưu, hoặc có ARDS nặng.

\subsection{6. Điều trị tăng áp lực động mạch phổi}

- Hạn chế kích thích hệ thần kinh giao cảm: (1) Duy trì thuốc an thần sâu kết hợp với thuốc giãn cớ. (2) Hỗ trợ nồng độ oxy cao trước và trong khi hút nội khí quản. (3) Duy trì thân nhiệt bình thường.

- Điều trị làm giảm sức kháng mạch máu phổi: (1) Thông khí nhân tạo với Vt thấp và PEEP phù hợp không quá cao. (2) Duy trì $\mathrm{PaO}_{2} 80-100$ mmHg. (3) Kiềm hóa máu bằng thông khí nhân tạo hoặc truyền bicarbonate. (4) $\mathrm{pCO}_{2}$ kiểm soát ở mức 30-35 mmHg.

- Điều trị các thuốc giãn mạch phổi: NO; Iloprost; Sidernafil.

- Điều trị hỗ trợ thất phải: Milrinone: giảm hậu gánh cho thất phải; Các thuốc vận mạch hỗ trợ thất phải: Dopamin, dobutamin hoặc adrenalin; Trường hợp tụt huyết áp không hồi phục phải dùng vasopressin.

4.2.7. Chỉ định màng trao đổi oxy ngoài cơ thể (ECMO) Áp dụng nếu có điều kiện

Chỉ định ở bệnh nhân ho gà rất nặng có tình trạng suy hô hấp nặng không đáp ứng với thở máy thông lệ, sốc tim và tăng áp lực động mạch phổi nặng. ECMO còn giúp giảm lượng bạch cầu do hoà loãng máu của thể tích dịch ban đầu đưa vào.

\section{PHÒNG BÊNH}

\subsection{Phòng bệnh không đặc hiệu}

\subsubsection{Cách ly}

Ngoài các biện pháp dự phòng chuẩn, các biện pháp dự phòng bệnh lây truyền qua đường hô hấp được khuyến cáo áp dụng ít nhất 5 ngày sau khi bắt đầu điều trị kháng sinh nhóm macrolide cho người mắc bệnh.
5.1.2. Phòng bệnh cho người thân và những người phơi nhiễm khác

- Dự phòng sau phơi nhiễm (Postexposure prophylaxis - PEP) bằng kháng sinh nhóm macrolide cho tất cả những người trong gia đình có tiếp xúc với trẻ ở bất kỳ tuổi nào, tiền sử tiêm phòng và có biểu hiện triệu chứng hay không.

- Tiêm phòng cho những người tiếp xúc gần cũng nên được xem xét.

\subsection{Khuyến cáo tiêm phòng vắc xin ho gà}

Trong vài thập kỷ qua, chương trình tiêm chủng vắc xin ho gà đã đem lại hiệu quả cao về miễn dịch giúp phòng được ho gà nặng cho trẻ em trên toàn thế giới. Có hai loại vắc xin ho gà sẵn có: vắc xin ho gà toàn bào (whole cell - wP) tạo từ xác vi khuẩn ho gà, và loại vô bào (acellular - aP) - chỉ sử dụng một số kháng nguyên vi khuẩn ho gà [2].

\subsubsection{Các loại vắc xin}

- Vắc xin ho gà toàn bào (wP):

Vắc xin wP được sản xuất từ vi khuẩnnuôi cấy có chọn lọc chủng Bordetella pertussis sau đó được xử lý bởi nhiệt hoặc formalin vàthường được kết hợp với biến độc tố bạch hầu, uốn ván tạo sản phẩm DTwP. Một số loại vắc xin tổng hợp tiêm chủng cho thời kỳ trẻ sơ sinh và trẻ nhỏ có thể kết hợp thêm $H$. Influenzae nhóm $B(\mathrm{HiB})$, và viêm gan $B$ (HepB). Có thể kết hợp thêm cả virus bại liệt bất hoạt dạng tiêm (IPV). Vắc xin cho phép sử dụng từ 6 tuần tuổi.

- Vắc xin ho gà vô bào (aP):

Các vắc xin này chứa một hoặc nhiều kháng nguyên tinh chế: PT, FHA, PRN, FIM type 2 và 3 . Các loại vắc xin khác nhau có chứa số loại kháng nguyên khác nhau, nồng độ thành phần các kháng nguyên khác nhau, mà có chỉ định sử dụng cho trẻ lớn ở nhiều sản phẩm khác nhau[1].

\subsubsection{Lịch tiêm chủng và các khuyến cáo}

Khuyến cáo tiêm phòng ho gà trong Chương trình TCMR Quốc gia

Thông tư 38/2017/TT-BYT ngày 17/10/2017 của Bộ Y tế ban hành danh mục bệnh truyền nhiễm, phạm vi và đối tượng phải sử dụng vắc xin, sinh phẩm Y tế bắt buộc[27] 
PHẦN TỔNG QUAN

\begin{tabular}{|c|l|l|}
\hline STT & Tuổi của trẻ & \multicolumn{1}{c|}{ Vắc xin sử dụng } \\
\hline 1 & 02 tháng & $\begin{array}{l}\text { Tiêm vắc xin bạch hầu - ho gà - uốn ván - viêm gan B - Hib mũi } 1 \text { mũi } 1 \text { (vắc xin } 5 \text { trong 1). } \\
\text { Uống vắc xin bại liệt lần } 1\end{array}$ \\
\hline 2 & 03 tháng & Tiêm vắc xin bạch hầu - ho gà - uốn ván - viêm gan B - Hib mũi 1 mũi 2. Uống vắc xin bại liệt lần 2 \\
\hline 3 & 04 tháng & Tiêm vắc xin bạch hầu - ho gà - uốn ván - viêm gan B - Hib mũi 3. Uống vắc xin bại liệt lần 3 \\
\hline 4 & 18 tháng & Tiêm vắc xin bạch hầu - ho gà - uốn ván mũi 4 \\
\hline
\end{tabular}

Gân đây các Tổ chức Y tế toàn câu (WHO, CDC, Hội YHDP Việt Nam) khuyến cáo tiêm phòng nhắc lạinhư'sau:

- Lứa tuổi tiền học đường:nên tiêm nhắc lại DTaP cho trẻ ở lứa tuổi 4 - 7 tuổi.

- Phụ nữ lứa tuổi sinh đẻ: tiêm nhắc 1 lần Tdap lúc 12 - 13 tuổi.

- Phụ nữ mang thai: có thể tiêm vắc xin bạch hầu - uốn ván - ho gà (Tdap) cho bà bầu được khuyến cáo khi mang thai vào khoảng tuần 27-36, giúp bảo vệ em bé chống lại tác nhân gây bệnh ho gà ngay từ khi sinh.

\section{TÀI LIÊUU THAM KHẢO}

1. Viện Vệ sinh y tế công cộng TP. Hồ Chí Minh, Bệnh ho gà (2012).

2. W.H.O., Pertussis vaccines. WHO position paper. 90: , 2015: p. 433-460.

3. Đỗ Thị Thúy Nga, Dương Thị Hồng. Hiệu quả điều trị bệnh ho gà ở trẻ em tại Bệnh viện Nhi Trung ương. Tạp chí $Y$ học dự phòng, 2016. Tập 26 (số 5 (178)): p. 57.

\section{2008, P.a.P.o.P.i.d.}

5. Paddock, C.D., et al., Pathology and pathogenesis of fatal Bordetella pertussis infection in infants. Clin Infect Dis, 2008. 47(3): p. 328-38.

6. (2011), W.-r.s.s.o.p., 2011.

7. WHO, Pertussis. https://www.who.int/ health-topics/pertussis\#tab=tab_1, 2018.

8. CDC, Pertussis (Whooping Cough). https:// www.cdc.gov/pertussis/surv-reporting.html, 2018.
9. Son, S., et al., Prospective multinational serosurveillance study of Bordetella pertussis infection among 10- to 18-year-old Asian children and adolescents. Clin Microbiol Infect, 2019. 25(2): p. 250.e1-250.e7.

10. Thisyakorn, U., et al., Pertussis in the Association of Southeast Asian Nations: epidemiology and challenges. Int J Infect Dis, 2019. 87: p. 75-83.

11. Tiêm chung mở rộng quốc gia, Thành quả tiêm chủng mở rộng, Chương trình tiêm chủng mở rộng www.tiemchungmorong.vn. 2013.

12. Đỗ Thiện Hải, Dương Thị Hồng, Đỗ Thúy Nga, Dịch tễ học bệnh ho gà ở trẻ em tại Bệnh viện Nhi Trung ương giai đoạn 2012 -2014. Tạp chí Y học Dự phòng, 2016. XXVI, số 6 (179)(6(179)).

13. Xoay, T.Đ., Mô tả đặc điểm lâm sàng và các yếu tố liên quan tử vong ở bệnh ho gà nặng tại khoa Điều trị tích cực Bệnh viện Nhi Trung ương. 2019.

14. Zamanian R.T, H.F., Doyle R.L. (2007) "Management strategies for patients with pulmonary hypertention in the intensive care unit". Crit Care Med, 35, 2037-2050.

15. Long S.S., P.C.G., Bordetella pertussis (Pertussis) and other Species. Principles And Practice Of Pediatric Infectious Diseases; . Elsevier, Churchill livingstone, Philadelphia, USA, 2012: p. 865-873.

16. Đỗ Thiện Hải, Đỗ Thị thúy Nga và cộng sự. Đánh giá kháng thể lgG kháng ho gà ở các bà mẹ có trẻ dưới 3 tháng tuổi mắc và không mắc bệnh ho gà tại Bệnh viện Nhi Trung ương, Hà Nội, năm 2017 - 2018. Tạp chí Y học Dự Phòng, 2019. 
17. Skoff, T.H., et al., Sources of Infant Pertussis Infection in the United States. Pediatrics, 2015. 136(4): p. 635-41.

18. Schmitt-Grohé, S., et al., Pertussis in German adults. Clin Infect Dis, 1995. 21(4): p. 860-6.

19. Edwards KM DM (2004). Pertussis vaccine. VaccinesPA: Saunders, P., 471-528.

20. Mallet, E., et al., Antibody persistence against diphtheria, tetanus, pertussis, poliomyelitis and Haemophilus influenzae type $b$ (Hib) in 5-6-year-old children after primary vaccination and first booster with a pentavalent combined acellular pertussis vaccine: immunogenicity and tolerance of a tetravalent combined acellular pertussis vaccine given as a second booster. Vaccine, 2004. 22(11-12): p. 1415-22.

21. Cherry, J.D., Pertussis in the preantibiotic and prevaccine era, with emphasis on adult pertussis. Clin Infect Dis, 1999. 28 Suppl 2: p.S107-11.

22. Kreeftenberg, J.G., Standardization of acellular pertussis vaccines. Biologicals, 1999. 27(2): p. 115-7.

\section{Centers for Disease Control, P.U.r., et al.}

24. Phương., N.T.L., "Xây dựng phương pháp đánh giá một số kháng nguyên trong vắc xin ho gà và đề xuất quy trình sản xuất vắc xin ho gà an toàn cao tại Viện vắc xin Nha Trang. Luận án Tiến sĩ Y học, Viện Vệ sinh dịch tễ Trung ương, 2007.

25. Heininger, U., et al., Clinical Validation of a Polymerase Chain Reaction Assay for the Diagnosis of Pertussis by Comparison With Serology, Culture, and Symptoms During a Large Pertussis Vaccine Efficacy Trial. Pediatrics, 2000. 105: p. E31.

26. Winter, K., et al., Risk Factors Associated With Infant Deaths From Pertussis: A Case-Control Study. Clin Infect Dis, 2015. 61(7): p. 1099-106.

27. Bộ Y tế, Thông tư 38/2017/TT-BYT ngày 17/10/2017 của BộY tế ban hành danh mục bệnh truyền nhiễm, phạm vi và đối tượng phải sử dụng vắc xin, sinh phẩm y tế bắt buộc. 2017. 